\title{
NORA WITTMANN \\ Reparations - Legally Justified and Sine qua non for Global Justice, Peace and Security
}

\begin{abstract}
The paper assesses current rising reparations claims for the Maafa/ Maangamizi ('African holocaust,' comprising transatlantic slavery, colonialism and neo-colonialism) from two angles. First, it explores the connectivity of reparations and global justice, peace and security. Second, it discusses how the claim is justified in international law. The concept of reparations in international law is also explored, revealing that reparations cannot be limited to financial compensation due to the nature of the damage and international law prescriptions. Comprehensive reparations based in international law require the removal of structures built on centuries of illegal acts and aggression, in the forms of transatlantic slavery, colonialism and neocolonialism. Reparations must also lead to the restitution of sovereignty to African and indigenous peoples globally. They are indispensable to halt the destruction of the earth as human habitat, caused by the violent European cultural, political, socioeconomic system known as capitalism that is rooted in transatlantic slavery.
\end{abstract}

Keywords: capitalism; global justice; international law; reparations; sovereignty

\section{Introduction}

The present paper assesses the scope of law as a justification for the global African reparations claim, not only for transatlantic slavery but also for the Maafa/Maangamizi ('African holocaust,' comprising transatlantic slavery, colonialism and neo-colonialism $)^{1}$ at large, as well as the legal implications of this claim. This focus on law, not justice (a moral concept), is crucial because of the difference it makes in terms of whether people suppose that they have a rightful legal claim or just a good moral argument. If there is a legally valid reparations claim based in international law for transatlantic slavery and the Maafa at large, both African and non-African people should be aware of it. The formation of legal consciousness about the right to reparations being well anchored in law, and not just demanded by justice and morality, cannot be underestimated for the self-repair of African people.

In light of the rising reparations movement and the legal justification of the claim, the illumination of the connection between the Maafa, and therefore the

1 Some reparation activists employ the concept of Maafa when designating the crime (comprising its different stages of slavery, colonialism and neo-colonialism) for which reparation is sought. Maafa is a Kiswahili word meaning 'disaster,' and it is used to describe the over 500 years of warfare and genocide experienced by African people under enslavement and colonialism and their continued impact on African people throughout the world. The term was introduced by anthropologist Marimba Ani (see: Marimba Ani, Let The Circle Be Unbroken: The Implications of African Spirituality in the Diaspora (New York: Nkonimfo Publications, 1988)). Others use the term Maangamizi, coined by Maulana Karenga, which is also a Kiswahili term meaning 'holocaust.' 


\section{REPARATIONS - LEGALLY JUSTIFIED AND SINE QUA NON FOR GLOBAL JUSTICE, PEACE AND SECURITY}

global African reparations claim arising from it, and a host of contemporary problems that humanity not just faces but that actually endanger its very existence also appears important. Massive and life-destroying pollution of our environment, racism, poverty and industrial warfare all arguably have their causes in the current unjust world system. As I, and others scholars, have argued, the current world system is rooted in and has been established through transatlantic slavery. ${ }^{2}$ Some will interject that other violations and crimes, such as native genocide, colonialism and general resource exploitation also contributed later to shape our current world; yet, all these violations were built onto the foundation laid with transatlantic enslavement and were only made possible because transatlantic enslavement had preceded them and laid that foundation. That European powers could colonise large parts of Asia destroying traditional socio-economic systems and plunging people into a never-before-known misery ${ }^{3}$ - due to the wealth they had generated over at least 250 years of kidnapping millions of Africans and forcing them to work for free. ${ }^{4}$ Capitalism as a system is clearly a Western/European creation that has been formed out of transatlantic slavery and has, in the time since, been unleashed over the entire globe. In its constitutive phase, capitalism depended on transatlantic slavery; today, it depends on the continuation of the Maafa/ Maangamizi. Thus, reparations for slavery and colonialism, being at the root of the numerous fundamental wrongs implemented at a structural and global level, arguably constitute a condition sine qua non to approach global justice and mitigate the abovementioned hazards. This challenge of repairing past wrongs that still very much structure the present is not only about redistribution of wealth but, importantly, also about sovereignty and a change in global power relations.

The sustained crime of transatlantic slavery, merging into colonialism and then neo-colonialism, was fundamental in carving out and instituting the world system and global power structures that still direct our reality today. It can be deemed fundamental because, put simply, before the assault of transatlantic enslavement, European people were a global minority ${ }^{5}$ and not a particularly powerful one, whereas after and until now, European and Europeandescended people strongly hold most global power poles. Transatlantic slavery

2 W. E.B. DuBois, The World and Africa (New York: International Publishers, 1965); Walter Rodney, How Europe underdeveloped Africa (London, Bogle-L'Ouverture Publications, 1972); Eric Williams, Capitalism and Slavery (Richmond: University of North Carolina Press, 1944).

3 Reports and papers of the meeting of experts organized by UNESCO at Port-au-Prince, Haiti, 31 January to 4 February 1978, The General History of Africa: Studies and Documents. The African Slave Trade from the Fifteenth to the Nineteenth Century (Paris: UNESCO, 1979).

4 DuBois (1965); Rodney (1972); Williams (1944).

5 Guillaume Wunsch, Graziella Caselli and Jacques Vallin, Demography - Analysis and Synthesis: A Treatise in Population (London: Academic Press, 2006). 
was also fundamental in shaping the current world system because the same violent structures and mechanisms employed to begin and preserve transatlantic slavery are still violently maintained today to ensure the continued running of the Eurocentric capitalist world order. These structures and mechanisms include the kidnapping and removal of disobedient rulers, the spreading of misinformation and the looting of vast resources from the African, Asian and South American continents for the pleasure and comfort of Europeans and Western elites and - with the passage of time - their constituencies. These mechanisms are still at the core of the current world system and are responsible for the great gaps in wealth and power between white and non-white people, both within national societies and on a global scale, as well as between local and global elites and common people. Since 'reparation(s),' if performed according to international law, 'must, as far as possible, wipe out all the consequences of the illegal act and re-establish the situation which would, in all probability, have existed if that act had not been committed, ${ }^{6}$ reparations cannot stop short at distributing wealth to African and Black people. Indeed, the international crimes of transatlantic slavery and, building right onto it, colonialism are so formative in the current world order's makeup and structure that global justice cannot be attained without remedying these crimes through comprehensive reparations.

Over the next pages, I will assess why reparations for the Maafa/Maangamizi (transatlantic enslavement, colonialism and neo-colonialism) are both legally due and necessary, not only for African people globally but also for humanity at large. I will subsequently discuss how reparations ought to be conceived and what the term circumscribes.

\section{Global Apartheid, International Law and the Case for Global African Reparations}

While writing these pages, I am sitting in Kingston, Jamaica, a society constructed on the sweat and blood of transatlantic slavery. The majority of the people who live on this island are here for the sole reason that their ancestors were illegally kidnapped and deported while the societies and nations of their homeland, Africa, were violently destroyed and plundered by the same European states, entities and agents who had deported them. At present, Jamaica has one of the highest crime and murder rates worldwide. ${ }^{7}$ As unfortunate as it is, this state of affairs is barely surprising: virtually everything, from simple food items to deodorant to transportation, is significantly more expensive here

6 Permanent Court of International Justice, The Factory at Chorzów (Germany v. Poland), Judgement of 13 September 1928, PCIJ Ser. A., No. 17, p. 40.

7 Overseas Security Advisory Council (OSAC) (2016), 'Country Report Jamaica', <https://www.osac.gov/pages/ ContentReportDetails.aspx?cid $=19562>($ accessed 23 September 2016) 


\section{REPARATIONS - LEGALLY JUSTIFIED AND SINE QUA NON FOR GLOBAL JUSTICE, PEACE AND SECURITY}

than in Europe and the US while unemployment, poverty and political violence rank very high. ${ }^{8}$ Beckles ${ }^{9}$ and others ${ }^{10}$ have properly assessed how the current social, political and economic problems that plague Jamaicans, affecting their life quality and span, are not only causal effects of the legacy of slavery but also expressions of the Maafa/Maangamizi's continuing crime. It cannot be denied that if the crime of transatlantic slavery had not happened, the majority of Black people in Jamaica would not be trapped as the poor in ghetto slums on a small island but would live in Africa, and importantly, in an Africa that would not have been devastated by sustained violence for over more than 500 years. ${ }^{11}$ Therefore, it is no exaggeration to state that the vast majority of Jamaicans are, in effect, trapped on this island. The US and Western European states, having built their fortune on the enslavement and plunder of Africa and Africans, make it very hard for Jamaicans to obtain visas. Yet, even to reach Africa by plane, Jamaicans have to travel through Europe or the US, and the ticket costs much more than what most people can afford.

This state of affairs is also an expression of one of the most striking consequences of the 500 years of sustained violence against Africa and Africans since the onset of transatlantic slavery. Therefore, today, we are in a situation of global apartheid. Peace researcher Gernot Köhler ${ }^{12}$ notes that the

notion of apartheid is most apt for denoting the current world situation in which a minority race (of whites and honorary whites) dominates the majority of humanity, which is composed of a variety of 'peoples of colour.' In its global, de facto form, apartheid is even more severe than its South African exemplar. The disparities in wealth, power, military control, health, and life expectancy that characterise the world system or global macro-society are extremely wide and growing. (...) [G]lobal apartheid with its built-in forms of structural violence is consistent with what sociologist Howard Winant (...) describes as the global racial entity we know as capitalism, whose genealogy implicates the compounding and interdependence of race

8 Jamaica Observer(30 April 2015), 'Morepeopleunemployed in Jan 2015 than Jan 2014', <http://www.jamaicaobserver. com/news/More-people-unemployed-in-Jan-2015-than-Jan-2014---STATIN> (accessed 15 December 2015)

9 Hilary Beckles, Britain's Black Debt. Reparations for Caribbean Slavery and Native Genocide (Kingston: University of the West Indies Press, 2013)

10 Brigitte K Matthies, Julie Meeks-Gardner, Avril Daley and Claudette Crawford-Brown, 'Issues of Violence in the Caribbean' in Frederick W. Hickling, Brigitte K. Matthies, Kai Morgan and Roger C. Gobson (eds.), Perspectives in Caribbean Psychology (Kingston: CARIMENSA, 2008), 393-464, p. 398 et seq.

11 Klah Popo, Histoire des ,Traites Négrières'. Critique afrocentrée d'une négrophobie académique (Paris: Anibwe, 2010), 59-62 ; Louise Diop-Maes, 'Evolution de la population de l'Afrique Noire du neolithique au milieu du $20 e m e$ siecle', Ankh Nr. 2 (1993), 182-212.

12 Gernot Köhler, 'Global Apartheid', reprinted in William A. Haviland and Robert J. Gordon (eds.), Talking About People: Readings in Contemporary Cultural Anthropology (Mountain View: Mayfield, 2002), 262-268. 
and class. Winant reminds us that in virtually every corner of the earth, dark skin still correlates with inequality. ${ }^{13}$

At the time of writing this paper, we are tragically reminded of this by the multiple instances of police killings of Black people in the United States of America. This unbearable situation, with its roots in transatlantic slavery, was thus also recently highlighted by the findings and recommendation of reparations to be made by the UN Working Group of Experts for People of African Descent, which stated that

(t)he colonial history, the legacy of enslavement, racial subordination and segregation, racial terrorism, and racial inequality in the US remains a serious challenge as there has been no real commitment to reparations and to truth and reconciliation for people of African descent. (...) Contemporary police killings and the trauma it creates are reminiscent of the racial terror lynching of the past. Impunity for state violence has resulted in the current human rights crisis and must be addressed as a matter of urgency. ${ }^{14}$

As Harrison writes, on a global level apartheid is

a de facto structure... which combines socio-economic and racial antagonisms and in which (1) a minority of whites occupies the pole of affluence, while a majority composed of other races occupies the pole of poverty; (2) social integration of the two groups is made extremely difficult by barriers of complexion, economic position, political boundaries, and other factors; (3) economic development of the two groups is interdependent; and (4) the affluent white minority possesses a disproportionate share of the world society's political, economic, and military power. ${ }^{15}$

Haviland stresses that the system of global apartheid reposes on structural violence, engendering 'situations' such as world hunger and pollution. He traces the sources of humanity's major contemporary problems to enduring race-class inequalities. ${ }^{16}$ As several scholars have elaborated, race-class inequalities are rooted in transatlantic slavery. ${ }^{17}$

13 Howard Winant, Racial Formation and Hegemony: Global and Local Developments in Racial Conditions: Politics, Theory, Comparisons (Minneapolis: University of Minnesota Press, 1994), p. 221.

14 Statement to the media by the United Nations' Working Group of Experts on People of African Descent, on the conclusion of its official visit to USA, 19-29 January 2016, <http://www.ohchr.org/EN/NewsEvents/Pages/ DisplayNews.aspx?NewsID=17000\&LangID=E $>$ (accessed 12 May 2016)

15 Faye Harrison, 'Anthropology as an Agent of Transformation: Introductory Comments and Queries' in Faye Harrison (ed.), Decolonizing Anthropology. Moving Further toward an Anthropology for Liberation (Arlington: American Anthropological Association, 2010), 1-15, p. 3.

16 William A Haviland, Cultural Anthropology, Sixth Edition (Fort Worth: Holt, Rinehart and Winston, 1990)

17 Nathan Nunn, 'The Long Term Effects of Africa's Slave Trades', Quarterly Journal of Economics 123/1 (2008),139176; Haviland (1990); Joseph E. Inikori, Forced Migration. The Impact of the Export Slave Trade on African Societies (New York: Africana Publishing Company, 1982); Joseph E. Inikori, The Chaining of a Continent. Export Demand for Captives and the History of Africa South of the Sahara, 1450-1870 (Kingston: Institute of Social and Economic Research, UWI, 1992). 


\section{REPARATIONS - LEGALLY JUSTIFIED AND SINE QUA NON FOR GLOBAL JUSTICE, PEACE AND SECURITY}

This situation of global apartheid has also been recognised by the UN Working Group of Experts on People of African descent, which confirmed the 'structural discrimination' of African people on a global level and issued recommendations to counter this state of affairs. ${ }^{18}$ Today, in South Africa, for example, 20 years after the end of formal apartheid and colonialism, 'white' people as descendants of the colonisers still own $80 \%$ of the land, to the effect that Black South Africans cannot even find space to bury their dead. ${ }^{19}$ In Namibia, 90\% of good land is in the hands of about 4000 white descendants of colonisers. ${ }^{20}$ The assault on these regions by European states, companies and individuals began in the era of transatlantic enslavement, intensified in the colonial era and persists to this day. $^{21}$

Now, the International Convention on the Suppression and Punishment of the Crime of Apartheid declares apartheid a crime against humanity; ${ }^{22}$ legal experts generally categorise apartheid either as a crime against humanity or genocide, where the latter aims at the intentional destruction of groups. ${ }^{23}$ Both categories of international crimes oblige all States to contribute towards ending such unbearable situations. As stated in the International Law Commission's (ILC)Articles on State Responsibility,

(i)n particular, all States in such cases have an obligation to cooperate to bring the breach to an end, not to recognise as lawful the situation created by the breach, and not to render aid or assistance to the responsible State in maintaining the situation so created.' $(\text { Art. } 40,41)^{24}$

The existence of such an obligation of non-recognition in response to serious breaches of obligations arising under peremptory norms also finds support in international practice and the decisions of the International Court of Justice (ICJ). ${ }^{25}$ The International Convention on the Suppression and Punishment of the Crime of Apartheid, referencing the framework of the World Conference against Racism, Racial Discrimination, Xenophobia and Related Intolerance, where reparations were also high on the agenda, stated 'that the international

18 Working Group of Experts on People of African Descent, 'CONCLUSIONS AND RECOMMENDATIONS', IX Session, April 12-16, 2010, <http://www2.ohchr.org/english/issues/racism/groups/african/docs/session9/Conclusions_ RecommandationsIXSession.doc > (accessed 15 December 2015)

19 Motsoko Pheko, 'Land Is Money, Power and Freedom', New African 550 (2015), 26-27, p. 27.

20 Baffour Ankomah, 'Mercury Rising! Namibia: Land of the Brave?', New African 550 (2015), p. 12.

21 Nunn (2008).

22 General Assembly of the United Nations (1973), 'International Convention on the Suppression and Punishment of the Crime of Apartheid', <http://www.hrea.org/index.php?base_id=104\&language_id=1\&erc_doc_id=93o\&category_ id=35\&category_type $=3 \&$ group $=>$ (accessed 15 December 2015)

23 William A. Schabas, Genocide in International Law (Cambridge: Cambridge University Press, 200o).

24 Crawford (2002), p. 192.

25 Ibid., p. 250. 
community should consider the causes and consequences of those ills which, historically, have been brought about largely by slavery, colonialism and wars of conquest' and also recalled that

the historic responsibility of the relevant Powers towards the peoples whom they colonised or reduced to slavery should be the subject of solemn and formal recognition and reparation. (...) [T] his responsibility is all the more well-founded since the periods of slavery and colonialism have brought about a state of economic collapse in the countries concerned, serious consequences in the social fabric and other tragedies which continue even today to affect entire peoples throughout the world. ${ }^{26}$

\section{Economic Justice and Sovereignty}

Thus, reparations are not just for a horrific past. The strategies employed and mechanisms implemented to begin and preserve transatlantic slavery are the same and are still violently maintained today in the exploitation of global - continental and diasporic - Africa. During the period of transatlantic enslavement, European States and slavers armed corruptible African individuals while interest groups played out one group against the next and dispensed with rulers and leaders who defended their people to the detriment of European economic interests. ${ }^{27}$ European and Western states in our times also do what they can to prevent the rise and success of African leaders working for the betterment of African people in ways that challenge Western capitalist hegemony, thereby posing a serious threat to the structures established during transatlantic slavery that still uphold Western economy today. This is what happened to Patrice Lumumba in Congo, Thomas Sankara in Burkina Faso, Eduardo Mondlane in Mozambique, Ruben Um Nyobe in Cameroun, Sylvanus Olympio in Togo or Amilcar Cabral in Guinea-Bissau. ${ }^{28}$ Though Muammar Gaddafi was a horrible dictator, it has been argued that he was killed by NATO because of his heavy investment in a gold-based Pan-African currency, the realisation of which would have gravely hurt Western economic and geopolitical interests. ${ }^{29}$

26 Sub-Commission on Human Rights (2002), 'Recognition of responsibility and reparation for massive and flagrant violations of human rights which constitute crimes against humanity and which took place during the period of slavery, colonialism and wars of conquest', (Resolution 2002/5), <http://ap.ohchr.org/documents/E/SUBCOM/ resolutions/E-CN_4-SUB_2-RES-2002-5.doc> (accessed 17 September 2015)

27 Nora Wittmann, Slavery Reparations Time Is Now. Exposing Lies, Claiming Justice for Global Survival - An International Legal Assessment (Vienna: Power of the TrInIty Publishers, 2013), p. 383-394.

28 Ibid.

29 Stephan Gowans, NATO's War on Libya and Africa', Global Research, (2012), <http://www.globalresearch.ca/natoswar-on-libya-and-africa/5311323>; Brad Hoff (2016), 'Hillary Emails Reveal True Motive for Libya Intervention', Foreign Policy Journal, <http://www.foreignpolicyjournal.com/2016/o1/o6/new-hillary-emails-reveal-true-motivefor-libya-intervention/> (accessed 23 August 2016); Horace Campbell, Global NATO and the Catastrophic Failure in Libya (New York: Monthly Review Press, 2013). 


\section{REPARATIONS — LEGALLY JUSTIFIED AND SINE QUA NON FOR GLOBAL JUSTICE, PEACE AND SECURITY}

This pattern of undermining the sovereignty of African and indigenous nations can be traced through colonialism directly to transatlantic slavery. Professor Inikori has documented its disastrous consequences on people's lives in Africa in the past in a project facilitated by UNESCO. According to Inikori, the response of African societies to the external pressure of transatlantic enslavement led to socio-economic and political structures and institutions that were not conducive to long-term economic development and competitiveness in the international economy. Between 1450 and 1870 , export demand for captives kept the total population of tropical Africa at a level that was far too low to stimulate the growth of internal trade, the diversification of the economy, the transformation of technology and the development of commodity production for export. To procure protection against slavers' activities, security became a far more important determinant of the choice of settlement than economic considerations, thus restricting the opportunities and incentives for economic growth, development and agricultural technology in Africa. With the heavy pressure exerted by European slavers, importing 20 million guns into Africa ${ }^{30}$ and arming collaborators, many African societies faced a situation of enslave your neighbour or be enslaved. In combination, these factors acted as a chain on tropical African societies and facilitated the imposition of European colonial domination, which structurally, technologically and mentally aggravated the problem. ${ }^{31}$ It was not only the high fatalities incurred by military operations, slave raiding and wars associated with transatlantic slavery that had serious consequences for the demographic process but the political and social upheavals engendered through these developments also had serious and lasting negative effects on economic activities. Inter-regional flows of goods were severely restricted, as were opportunities and incentives for innovation in agricultural technology. There can be no major doubt that this pattern seriously restricted the chances for economic growth and development in Africa. ${ }^{32}$ The people who were kidnapped and enslaved were in the prime of life and at their reproductive peak. Furthermore, the survival rate in Africa during the transatlantic slavery area was reduced due to the adverse conditions created by this massive enslavement. ${ }^{33}$ Evidence clearly shows that all the major regions of the world experienced considerable long-term population expansion between 1650 and 1850, even the survivors of the indigenous people in the Americas. Yet, during the same period, the population of Africa declined absolutely or remained

30 Paul Lovejoy, Transformations in Slavery. A History of Slavery in Africa, Second Edition (Cambridge: Cambridge University Press, 2000), p. 109.

31 Inikori (1982).

32 Ibid.

33 Ibid., p. 32. 
stagnant. ${ }^{34}$ All of this demands reparation.

The general insecurity engendered by transatlantic slavery led to the erosion of customs and values and undermined traditional social structures. The ever-present acute or lingering violence destroyed the functioning of institutions. Political rivalries between different factions inside societies created a climate of perpetual civil war, such as in Senegambia or Nigeria. ${ }^{35}$ Warfare became the most lucrative industry and led to the development of military aristocracies throughout the continent. ${ }^{36}$ New power groups and shortterm interests took over, leading to a general climate that encouraged war with neighbours rather than peace. New states, such as Ibadan, emerged whose very bases were the socio-political and economic structures of transatlantic enslavement. ${ }^{37}$ Inikori explained that the

kidnapping and sale for export of a few traders and other individuals from neighbouring territories, often led to complicated political problems ending up in some major wars. Good examples are the political complications which arose from the activities of the Ijebu slave traders in the western towns of the Ife kingdom, which eventually led to the Owu war in Yorubaland in the early 19th century. Similar political situations have been documented for Senegal and States in East Africa. Similarly, the proliferation of firearms in connection with the slave trade (...) contributed in some important ways to the incidence of warfare in sub-Saharan Africa during the slave trade era. Thus, it can be said that the export slave trade was a major cause of social conflict and warfare in pre-colonial Africa. ${ }^{38}$

Transatlantic enslavement installed a permanent state of war, inter- and intra-community violence, in the affected regions, that is, the vast majority of the African continent. It also led to a deep corruption of indigenous African systems of justice. All of this necessitates reparation.

It is very important to consider all these factors when discussing solutions to the current problems of poverty, corruption and the rule of law in contemporary Africa. It is indeed crucial to be 'backward looking' as effects cannot be healed or effectively remedied without taking care of the root of these effects, which lie in the past. It is also important to look 'backwards' to discern responsibilities.

34 Inikori (1992)

35 M'Baye Gueye, 'L'Afrique a la veille de la conquete' in Elikia M'Bokolo (ed.), L'Afrique entre l'Europe et l'Amerique. Le rôle de l'Afrique dans la rencontre de deux mondes 1492-1992 (Paris: UNESCO, 1995), 80-96, p. 94.

36 Adama Gueye, 'The impact of the slave trade on Cayor and Baol. Mutations in Habitat and Land Occupancy', in Sylvaine A. Diouf (ed.), Fighting the Slave Trade. West African Strategies (Athens: Ohio University Press, 2003), 50-61, p. 52.

37 Inikori (1992), p. 3.

38 Inikori (1982), p. 50. 


\section{REPARATIONS - LEGALLY JUSTIFIED AND SINE QUA NON FOR GLOBAL JUSTICE, PEACE AND SECURITY}

These connections between past and present cannot be considered to be merely speculative as historical research has established that the violent imposition of enslavement destroyed and corrupted indigenous African legal, social, political and economic systems. ${ }^{39}$

As part of a thorough reparation process, pre-Maafa African justice systems must be researched and rehabilitated. Cognizant of this situation, UNESCO initiated the slave route oral tradition project to help determine the present 'conflict relations between ethnic groups and lineages, which, in these countries, are for certain the consequence of the slave trade and slavery.' 40 This state of affairs also illustrates why reparations need to be more than financial and why aid programs, as advocated in the hegemonic distributive justice approach - being restricted to a superficial and cosmetic transfer of capital - to poor, exploited, formerly colonised countries without comprehensive, structural reparations, fall short of remedying poverty.

The multiplication of wars and slave raiding led to hunger (as fields often had to be abandoned due to general insecurity), an elevation of epidemics and hygiene regression. Doudou Diène, division director at UNESCO, asserted that the persistence and amplitude of contemporary human rights violations in Africa are undoubtedly connected with transatlantic slavery's silence regarding these aspects. ${ }^{41}$

Many African elite and ruling groups emerged and firmly established themselves only through their collaboration with European slavers and the use of firearms provided by them. These dominant interest groups still constitute the political and economic elite in Africa today. ${ }^{42}$ In general, this is also observed in several Caribbean countries, where corruption ranks high in state apparatuses that are always short of funds and trapped in the international white supremacist system of debt and neo-colonialism.

39 Inikori (1982); Inikori (1992); Pathé Diagne, 'African Political, Economic and Social Structures During This Period' in B.A. Ogot (ed.), General History of Africa V. Africa from the Sixteenth to the Eighteenth Century (Paris: UNESCO, 1992), 23-45, p. 24; E.J. Alagoa, 'Fon and Yoruba: the Niger Delta and the Cameroon' in B.A. Ogot (ed.), General History of Africa V. Africa from the Sixteenth to the Eighteenth Century (Paris: UNESCO, 1992), 434-452, p. 451; Djibril Tamsir Niane, Tradition orale et archives de la traite négrière (Paris: UNESCO, 2001), p. 12 ; James Silk, 'Traditional Culture and the Prospect for Human Rights in Africa' in Abdullahi An-Na'im and Francis M. Deng (eds.), Human Rights in Africa. Cross-Cultural Perspectives (Washington DC: The Brookings Institution, 1990), 290-328, p. 292 et seq.

40 Alaba Simpson, Oral Tradition Relating to Slavery and Slave Trade in Nigeria, Ghana and Benin (Paris: Unesco, 2004), p. 5 .

41 Doudou Diène, 'De la traite négrière au défi du développement: réflexions sur les conditions de la paix mondiale' in Doudou Diène (ed.), La chaîne et le lien. Une vision de la traite négrière (Paris: UNESCO, 1998), 21-23, p. 21.

42 Inikori (1992), p. 34. 
Given the massive depopulation caused by transatlantic slavery ${ }^{43}$ and the fact that the deported individuals constituted a vital part of the productive forces of the affected African communities, it is safe to say that African economic conditions would be on a significantly healthier level today if transatlantic slavery would never have occurred. ${ }^{44}$ Not only were the most productive young men and women taken away from Africa but with them also went a lot of know-how. ${ }^{45}$ Transatlantic slavery caused endemic under-development on the African continent through economic, social and cultural destruction over several centuries. Flourishing civilisations were destroyed, historically grown systems of governance mowed down, millions and millions of citizens brutally murdered or deported. From all this emerged a pattern of poverty and under-development that not only still affects practically every African on the continent today but is also actively maintained by the former perpetrator States of transatlantic slavery.

Those taken away were brought into the most brutal reality of slavery, lawlessness, extreme cruelty and suffering for which healing and reparation are still highly prioritised.

Beyond the relevance for African people and societies globally, it is also important to grasp the scope of the wider effects of transatlantic slavery. Many contemporary ills and problems that occupy the headlines these days are relevant to reparations. The European Union's current migration policy, that arguably cost the lives of tens of thousands of Africans drowned in the Mediterranean Sea, ${ }^{46}$ is aimed at preventing redistribution of ill-gotten wealth by any means. It is true that the EU migration policy is fuelled by nationalism as well as by wanting to protect the economy and welfare of the EU to a large extent; however, protecting the economy and welfare of the EU, in fact, comes back to preventing the redistribution of ill-gotten wealth. For decades, the EU has been closing its borders to the same people whose natural resources its member States and their enterprises have ransacked over centuries, leaving the native populations few other possibilities than trying to reclaim a tiny parcel of what was and is looted from them by embarking on dangerous, unfit vessels.

43 A UNESCO colloquium stated that 210 million Africans had been deported or killed in the course of transatlantic enslavement (United Nations Educational, Scientific and Cultural Organization (ed.), 'Meeting of Experts on the African Slave-Trade, Final Report', Port-au-Prince, Haiti, 31 January-4 February 1978, <http://unesdoc.unesco. org/images/ooo3/ooo333/o3336oeb.pdf >) (accessed 23 August 2016). Other researchers such as Maes-Diop put the numbers of total victims at 400 million (Diop-Maes (1993), p. 187).

44 Ibid.

45 Nerina Boschiero, 'La traite transatlantique et la responsabilité internationale des Etats' in Laurence Boisson de Chazournes, Jean-François Quéguiner and Santiago Villalpando (eds.), Crimes de l'histoire et réparations : les réponses du droit et de la justice (Brussels: Editions Bruylant, 2004), 203-262, p. 205.

46 Jack Shenker, 'Nato Units Left 61 African Migrants to Die of Hunger and Thirst', The Guardian, 8 May 2011, <http:// www.guardian.co.uk/world/2011/may/o8/nato-ship-libyan-migrants> (accessed 13 July 2016); Ruth Weinzierl and Ursula Lisson, Grenzschutz und Menschenrechte. Eine europarechtliche und seerechtliche Studie (Berlin: German Institute for Human Rights, 2007), p.19 ff. 


\section{REPARATIONS — LEGALLY JUSTIFIED AND SINE QUA NON FOR GLOBAL JUSTICE, PEACE AND SECURITY}

For centuries, Europeans have gone to other peoples' territories and destroyed not only their political cultures and constitutional principles but also their very livelihoods. Although it is a different argument with regard to Syrian and Middle Eastern refugees who are also migrating en masse into the EU right now, in what concerns African migrants and refugees, the issue cannot be separated from the continuing crime of the Maafa/Maangamizi that European and Western states have imposed on African people for several centuries.

Human presence on earth is currently and acutely endangered by the trappings of transatlantic slavery and colonialism, the massive and unbearable levels of pollution largely caused by capitalism and its philosophy, rooted in transatlantic slavery, of prioritising short-term profits over long-term costs. Eric Williams asserts that capitalism as a system is rooted in transatlantic enslavement. ${ }^{47}$ Historically, before transatlantic enslavement, no society considered the maximisation of profit and capital by any means necessary as its main aim and object. Reparations, as due by international law (see next paragraph), will need to address this.

\section{Reparations as Due by Law - Not Charity}

To assess and determine the reparations for slavery, international law must be seriously analysed. It subsequently becomes clear that reparations will not only mean payments or financial compensation but much more. As we are dealing with a claim that spans continents and reposes on crimes against humanity and genocide, from a legal perspective, international law determines what reparations need to be. The general rule of the international legal reparations regime, as laid out by the Permanent Court of International Justice in the Chorzow Factory case, is that 'reparation must, as far as possible, wipe out all the consequences of the illegal act and re-establish the situation which would, in all probability, have existed if that act had not been committed. ${ }^{48}$ Building on this fundamental principle, international law recommends different forms of reparations. ${ }^{49}$ Compensation as payments and financial settlements is a necessary part of reparations, but full reparation, such as that due by international law, comprises much more than money and includes deconstructing the structures of the current world order that are deeply anchored in transatlantic slavery and are still based on exploitation, colonial structures and violence. This claim for reparations is basically grounded in the continuing violation of international law that constitutes the Maafa/Maangamizi, beginning with

47 Williams (1944).

48 Permanent Court of International Justice, The Factory at Chorzów (Germany v. Poland), Judgement of 13 September 1928, PCIJ Ser. A., No. 17, p. 40.

49 James Crawford, The International Law Commission's Articles on State Responsibility. Introduction, Text and Commentaries (Cambridge: Cambridge University Press, 2002), p. 45. 
transatlantic enslavement, continued with colonialism and carried into the present through neo-colonialism. Since its beginning, the Maafa/Maangamizi, the African holocaust, has been characterised by sustained and organised violence amounting to genocide ${ }^{50}$ perpetrated by European powers against African people.

Article 34 of the ILC Articles states that '(f)ull reparation for the injury caused by the internationally wrongful act shall take the form of restitution, compensation and satisfaction, either singly or in combination, in accordance with the provisions of this Chapter, ${ }^{51}$ thus clarifying that full reparation may only be achieved through a combination of different forms of reparation. International law also generally recognises that the process of reparation needs to include the naming of responsibility, which is a starting point in the crucial aspect of healing because victims partially internalise the blame if those who are really responsible are not exposed..$^{52}$

Only a comprehensive reparations strategy, involving different forms of reparation such as restitution (repatriation), compensation (financial reparation for the genocide and stolen labour), satisfaction (assessment of what really happened and diffusion of that knowledge; the naming of responsibility) and cessation (abandonment of genocidal structures of exploitation), can repair this vast harm globally. 53

Restitution as the primary means of reparation provided by international law would translate into repatriation for those descendants of deported Africans who wish to return and would include a financial scheme that would allow them to rebuild their lives on the continent. It would also mean the restitution of nuclear and other mining sites and natural resources to African sovereignty. Of course, this will entail a contentious notion of rightful ownership and property rights. Yet, such a process is essential to bring about justice in the matter. As stated previously, compensation would be anything monetary. Satisfaction, a further means of reparation, would come in the form of an apology and through the official recognition of true African history. Finally, cessation would translate into the Western states desisting from exploiting African people through the structures built on transatlantic slavery, violently reinforced by colonialism

50 Wittmann (2013), p. 151-172.

51 International Law Commission, 'Draft Articles on Responsibility of States for Internationally Wrongful Acts', (2001), Supplement No. 10 (A/56/10), <http://www.unhcr.org/refworld/docid/3ddb8f804.html> (accessed 10 July 2015)

52 Wittmann (2013), p. 397.

53 International Law Commission, Draft Articles on Responsibility of States for Internationally WrongfulActs, November 2001, Supplement No. 10 (A/56/10), (2001), chp.IV.E.1, <http://www.unhcr.org/refworld/docid/3ddb8f804. html>; UN General Assembly, Basic Principles and Guidelines on the Right Remedy and Reparation for Victims of Gross Violations of International Human Rights Law and Serious Violations of International Humanitarian Law, resolution adopted by the General Assembly, 16 December 2005, A/RES/6o/147 (accessed 10 February 2016); Wittmann (2013), p. 421. 


\section{REPARATIONS - LEGALLY JUSTIFIED AND SINE QUA NON FOR GLOBAL JUSTICE, PEACE AND SECURITY}

and forcibly maintained to this day. It would manifest in the liberation and full independence of the French colonies Martinique, Guadeloupe and Guiana and the removal of the Queen of England as the Head of State of Jamaica, for example. In general, reparations through restitution, compensation, satisfaction and cessation would manifest in the reestablishment of African people's sovereignty.

Sovereignty of African and indigenous peoples, a centrepiece of comprehensive reparations, is essential in finding a solution to global poverty and health crises. It is essential because with the ill-gotten wealth and power derived from illegal transatlantic enslavement of African people, Europeans put themselves in the position to also colonise and destroy social and political organisation in other parts of the world, such as in India. However, the importance of sovereignty is not only blocked out in hegemonic development and liberal distributive justice discourses and policies but is also further dismantled. Sovereignty means to rule and determine one's own destiny. ${ }^{54}$ Thus, the primary question is not whether sovereignty would be granted to 'pre-Maafa groups, contemporary states or indigenous groups.' Pre-Maafa groups no longer exist as the whole of Africa and all its societies were profoundly touched, shaken up and restructured through the sustained violence of transatlantic enslavement and colonialism. African people must get sovereignty, in the sense of ruling their own affairs and destinies and dispose their abundant wealth, in whatever form they organise, whether it be as states, regions, indigenous groups, a continental organisation or a global Pan-African organisation. Massive environmental pollution, causing the deaths of countless Africans around the globe in countries such as Guadeloupe and Martinique (massive illegal pesticide contamination), Ghana (illegal dumping of toxic electronic waste from Europe), ${ }^{55}$ Ivory Coast or Somalia (illegal dumping of toxic European waste into the coastal sea), ${ }^{56}$ is rooted in transatlantic slavery. The continuing Maafa, as the same power structures that were violently installed with transatlantic slavery, still remain in place and enable this to happen as a means of exploiting African and formerly colonised peoples and thus maintain the European and Western capitalist lifestyle. Martinique and Guadeloupe, mainly inhabited by descendants of Africans deported in transatlantic slavery, have the highest incidences in certain cancers because the French state, which still occupies these countries, allowed French banana planters to continue using a highly toxic pesticide that had already been banned for a decade in the US. ${ }^{57}$

54 Carreau (2007), p. 352.

55 Nele Goutier, 'E-waste in Ghana: Where Death is the Price of Living Another Day' (2014), <http://www.theecologist. org/News/news_analysis/2503820/ewaste_in_ghana_where_death_is_the_price_of_living_another_day. html7th August 2014> (accessed 10 February 2016)

56 Environmental Justice Atlas, 'Somalia Toxic Waste Dumping' (2014), <https://ejatlas.org/conflict/somalia-toxicwaste-dumping-somalia> (accessed 10 February 2016)

57 TF1, 'Le chlordécone, le poison des Antilles', (2010), TV documentary, <http://lse.ac.uk/Workingpapers/Paper.pdf> (accessed 10 July 2015) 
As might be interjected, indigenous communities throughout the Americas also face similar problems pertaining to massive, sickness-causing pollution of their environment. Yet, this does not take away from the unbroken line of aggression and destruction of life perpetrated by the French and other European states as well as by private entities and individuals assisted by those same states against African and African-descended people. In 'French' Guiana, people suffer an array of illnesses caused by pollution from the French satellite base in Kourou as well as from gold mining, just as in Mali/Africa. In Guadeloupe, Martinique and Guiana, the economy is largely monopolised by Békés, descendants of French slavers and colonisers, who are protected by the French state. ${ }^{58} \mathrm{~A}$ solution for these problems will require a comprehensive global reparations strategy that prioritises sovereignty in the agenda. That such a comprehensive reparations process is global from its outset is so important because the structures just mentioned were not established in Martinique, Guadeloupe or Guiana individually but were violently imposed on African and indigenous peoples globally. For African and indigenous people in their majority to be able to rise out of sickness and poverty, massive reparations that consider the holistic picture are necessary.

In continental Africa, as in Jamaica and other places where Africans were illegally deported, the exploitation structures established from the time of transatlantic slavery make survival difficult for many people. Many Malian immigrants in Europe, for example, come from the Kayes region where massive gold exploitation is financed by several public European state banks and the World Bank. Yet, while these European States and European-dominated institutions finance the infrastructure needed to obtain the precious mineral, they provide no money for environmental protection measures against the pollution caused by the mining. Gold mining produces dust that is charged with mercury, arsenic, lead, cadmium and antimony. Local populations suffer from respiratory problems, water pollution, child death and stillbirths. People die of non-diagnosed diseases, many of them induced due to the cyanide that is used to treat the metal. ${ }^{59}$ Kayes, significantly, was a region that was also heavily affected by transatlantic enslavement and colonial forced labour. ${ }^{60}$

When uranium was discovered in Niger in the 1970s, President Hamani Diori wanted to index its price on oil. As soon as he proclaimed this plan, he was ousted from power by a former sergeant in the French army, Seyni Kountche. Not surprisingly, the price for uranium crumbled once Kountche came to power,

58 Wittmann (2013), p. 300.

59 Gilles Labarthe/Francois-Xavier Verschave, L'or africain. Pillages, trafics \& commerce international (Marseille: Agone, 2007). 60 Ibid. 


\section{REPARATIONS — LEGALLY JUSTIFIED AND SINE QUA NON FOR GLOBAL JUSTICE, PEACE AND SECURITY}

and Cogema, then the main French society stoping uranium, succeeded in making France the world's fourth biggest producer of uranium - even though it only possesses $4 \%$ of global resources - and the first producer of nuclear energy ( $80 \%$ of French energy today is nuclear). EDF, the French state energy company, claims to provide the 'cheapest energy of Europe.' In the meantime, many Nigerians live without electricity but are exposed to radioactivity. In the region where the uranium is stoped, a high incidence of cardiovascular disease, allergies, ectopic pregnancies and malformations is observed. ${ }^{61}$ Another example of the sustained sabotage of African people's sovereignty and the looting of their resources by Western enterprises and States that became prominent in the world because of the execution of activist and writer Ken Saro-Wiwa concerns Ogoni oil in Nigeria. The violence connected with its exploitation by Western oil companies resulted in war and death for African people. In Congo, there is a direct link between the exploitation of coltan, the continuation of war and the extermination of people. ${ }^{62}$ These few instances exemplify why comprehensive global African reparations, aiming at restoring African sovereignty, are both due and necessary for the African continent and diaspora.

\section{Transatlantic Slavery - The Illegal Base of the Current World System}

To fully grasp the righteousness of this reparations claim, we must understand that according to the relevant laws - African, European, international - of that time, transatlantic slavery was illegal when it was perpetrated. ${ }^{6}$ As the author has established in her doctoral thesis, transatlantic slavery violated general principles of international law as derived from the vast majority of national, regional and communitarian legal systems. Both the typical modes of enslavement - kidnapping, slave razzias and fraudulent criminal administration - and the genocidal treatment that enslaved Africans underwent violated these general principles of law. Virtually all legal systems restricted the legality of enslavement to cases of captivity in just wars - that is, legally regulated criminal conviction and self- or debt-bondage. In all legal systems, enslaved persons retained some rights, such as the right to life and the right to seek protection from gross abuse. Though contested, in the sense that it rebuts and disproves the hegemonic opinion on the matter, a thorough and unbiased analysis of the available historical documentation clearly establishes that transatlantic slavery violated general principles of law. ${ }^{64}$ During the centuries of transatlantic slavery, slavery remained illegal in all European nations, and even concerning the

61 Rosa Amelia Plumelle-Uribe, Traite des Blancs, Traite des Noirs. Aspects méconnus et conséquences actuelles (Paris: L'Harmattan, 2008), p. 172.

62 Wittmann (2013), p. 304.

63 Ibid., p. 138.

64 Wittmann (2013), p. 138-139. 
colonies, the vast majority of courts in Europe persistently upheld the illegality of genocidal transatlantic slavery, such as in France and Britain. Transatlantic enslavement and slavery also remained illegal in African states and societies, although the practice of some states and societies changed due to the European slavers' systematic imposition of violence on the continent. However, the fact remains that the legal precepts outlawing transatlantic enslavement remained in force, and the treatment meted out to enslaved Africans in the transatlantic system stayed illegal in European, African and other states' legal systems and thus constituted general principles of law. Such general principles of law, rooted in natural law yet recognised as positive law at the time of transatlantic slavery, remained in effect throughout the transatlantic system and are concretised today in the form of the explicit prohibition of genocide and crimes against humanity. By these general principles, transatlantic slavery clearly was and remained illegal throughout the long centuries of its perpetration. ${ }^{65}$ In this, it is also insignificant whether people of African descent were considered fully or sufficiently human to be counted as legal persons, as is sometimes interjected, as this view is just an expression of a Eurocentric, yet hegemonic, thought pattern. Such a view ignores that it was not up to Europeans, then a not very powerful global minority, to decide who was or who was not considered human. As testifies by legal historians and anthropologists, humans all over the globe also recognised themselves and others to be bound by international law. ${ }^{66}$

The principle of non-retroactivity in international law stipulates that crimes have to be legally appreciated by the laws in force at the time of their realisation. The legal status of transatlantic slavery - which is at the core of the reparations debate - must be assessed by the laws of the time. As the illegality of transatlantic slavery can be established by these laws, as I have demonstrated elsewhere, the responsibility of European perpetrator States and their obligation to make reparations are therefore engaged. European States, private entities and individuals have over illegally enslaved, murdered and robbed African and indigenous people around the globe, and infringed their sovereignty, thereby continuously violating applicable international law for a sustained period of roughly 500 years. Thus, they made themselves liable to reparations claims. They now bear an obligation to provide comprehensive reparations that, if the law is followed, will not only entail a massive redistribution of wealth and reduction in global poverty but will also repair the international power structures that still assure that the West continues to live off formerly colonised peoples by keeping them in poverty through violent and other means.

65 Ibid.

66 Arthur Nussbaum, A Concise History of the Law of Nations (New York: Macmillan Co, 1954), 36-73; José Capela, 'Ethique et représentation de l'esclavage colonial au Mozambique', in Isabel Castro Henriques and Louis Sala-Molins (eds.), Déraison, esclavage et droit. Les fondements ideologiques et juridiques de la traite negriere et de l'esclavage (Paris: EDITIONS UNESCO, 2002), p. 329-348. 


\section{REPARATIONS — LEGALLY JUSTIFIED AND SINE QUA NON FOR GLOBAL JUSTICE, PEACE AND SECURITY}

Building on the works of Mariamba Ani who has analysed transatlantic slavery as the initial phase of the Maafa's continuing crime, we observe a continuing violation of law. This assessment enables us to apply directly present-day international law and the ILC's Articles on State Responsibility and contemporary law provisions concerning genocide and crimes against humanity for the case of transatlantic slavery reparations. The question of reparation is to be appreciated on an ex iure basis and not an ex gratia one. African and indigenous peoples' rights do not depend on their former enslavers' and colonisers' good will. The claim for reparation rests on a sound legal basis. ${ }^{67}$ Though this reparations process will undoubtedly be a very complex one, the claim is well rooted in international law, stipulating clear obligations and rights. Furthermore, although this analysis runs counter to the hegemonic legal opinion that denies reparations claims on alleged legality of slavery and non-retroactivity grounds, all international legal scholars confronted with the author's doctoral thesis on this topic have subsequently changed their legal opinion in favour of recognising the reparations claim based in international law, such as ICJ Judge Patrick Robinson, who commented that the thesis 'presents an arguable case that at the relevant time slavery was illegal, (...) a prima facie case for the illegality of slavery, notwithstanding the difference in the practice followed in the colonies. ${ }^{\text {'68 }}$

As pertaining to the question regarding which actors would receive reparations, the answer is also complex and involves several interrelated levels - individual, state, regional and global. For example, all African people worldwide would benefit from the dismissal of global apartheid and would feel it in their personal lives, even though the measure would be directed and implemented at the level of the global power structure. Reparations restricted to financial measures can bring no justice to the cause as we are not simply faced with a question of global unequal distribution among individuals but fundamentally one of not only unequal but also unjust and violently imposed power relations along the lines of class and, importantly and interrelatedly, race. The current capitalist global economic and political system structures built on slavery, colonialism and racism are at the root of suffering and extreme poverty today. It is also significant that decades of 'aid' and 'assistance,' cornerstones of the hegemonic distributive justice paradigm, to Africa have not ameliorated the lives of the

67 Jean-Francois Gareau, 'Insoutenable imprescriptibilité à la lettre: Note sur l'interaction du temps, du droit et du symbole dans la problématique de la réparation des crimes de l'histoire' in Boisson de Chazournes, Laurence, JeanFrançois Quéguiner and Santiago Villalpando (eds.), Crimes de l'histoire et réparations: les réponses du droit et de la justice (Brussels: Editions Bruylant, 2004), 25-38, p. 33.

68 Correspondence with Patrick Robinson, President Judge of the UN International Criminal Tribunal for the former Yugoslavia, now at the ICJ (October 2012), on file with author. 
vast majority of people. ${ }^{69}$ On the contrary, in many African countries, such as in Burkina Faso, affliction is worse than it was in the 1960 s and 1970 s. $^{70}$

The question of which actors would receive financial compensation will need to be assessed by African people and agencies, such as states and civil society organisations. Some of this financial compensation would go into the building of schools, infrastructure and health facilities. The result of any reparation must ensure that the people who were wronged are able to enjoy the quality of life that they would have enjoyed had the wrongful act not been committed. African ${ }^{71}$ and indigenous peoples worldwide are claiming reparations, which include the respect of their sovereignty. ${ }^{72}$ Scientific assessments, headed by African scholars and scientists and drawing from historical, archaeological, sociological, medical, legal, political and economic disciplines will help in establishing what exactly is due and needed as reparations globally and locally.

\section{Right to the Dismissal of Capitalism}

Such comprehensive reparations, adhering to the precepts of international law, would result in a fundamental change in the global system and the end of capitalism as we know it. Transatlantic slavery, merging into capitalism and neocolonialism, stood at the root of capitalism and was essential for its emergence and rise, as elaborated by historian and former Prime Minister of Trinidad and Tobago Eric Williams in his seminal work Capitalism and Slavery. ${ }^{73}$

Thus, when reparations are implemented, adhering to the international law rule that 'reparation must, as far as possible, wipe out all the consequences of the illegal act and re-establish the situation which would, in all probability, have existed if that act had not been committed,' the core capitalist structures of the unlimited exploitation of people and nature will also be dismissed to restore the world to its pre-Maafa situation. Therefore, people in the West and in other nations 'successfully' emulating the Western mass production and consumption model by any means, such as upper- and middle-class China, will have to consume less and differently because the current system, on which the present throwaway society reposes, will be undermined by the reparatory process. There is no way around this. The hegemonic Western capitalist, liberal

69 Jeffrey D. Sachs, John W.M. Arthur, Guido Schmidt-Traub, Margaret Kruk, Chandrika Bahadur, Michael Faye and Gordon M. Cord, 'Ending Africa's Poverty Trap', UN Millennium Project (2004), <http://www.unmillenniumproject. org/documents/BPEAEndingAfricasPovertyTrapFINAL.pdf> (accessed 23 January 201)

70 Plumelle-Uribe (2008), p. 164.

71 As I have focused on reparations on transatlantic slavery and colonialism in Africa and their effects on African people globally today, the term 'African and indigenous peoples' "reparations"' is commonly used in this article. This is consistent with Marx's basic analysis of slavery as the means of primitive accumulation on which European capitalism was built and then expanded exploitation to other people worldwide.

72 Dale Turner, This Is Not a Peace Pipe: Towards an Understanding of Aboriginal Sovereignty (Montreal: McGill University, thesis paper, 1996), p. 146.

73 Williams (1944). 


\section{REPARATIONS - LEGALLY JUSTIFIED AND SINE QUA NON FOR GLOBAL JUSTICE, PEACE AND SECURITY}

model that most States emulate as politically correct with its holy grail of perpetual economic growth at any cost is killing us and the earth. It is crucial to understand that this system is not just environmentally unsustainable but that it also depends in its core functioning on the continued perpetuation of the Maafa/Maangamizi, the violent exploitation of people and theft of raw materials out of Africa; furthermore, its ideology (simply put as profit by any means) and historical base are in transatlantic enslavement and colonialism. ${ }^{74}$ Of course, to reach these comprehensive reparations, albeit due by law, massive people power will be needed. Thus, sensitisation and education are key, and the change will not occur overnight.

If we do not achieve comprehensive reparations and keep our consumption pattern and waste-culture, rooted in transatlantic slavery, one way or another, the West will always need to outsource the misery caused by its lifestyle's real costs to more or less geographically distant others. Therefore, it is important that the global reparations movement continues to highlight these interdependencies with other environmental and social justice movements. Reparations as due by international law include the cessation of the exploitation and theft of raw materials in Africa, without which global industries will have to develop production processes that depend less on resource spoliation. This will lead to a drastic decrease in global pollution. Global African and indigenous peoples' reparations will halt the deforestation of the Amazonian forests, the principal lungs of our planet, under the pressure of capitalist economic interests. Global reparations will pertinently engage the world in a serious examination of racism. This will subsequently have positive repercussions on ethnic conflicts all over the world, including in the Middle East.

Anti-capitalist and environmental activists all over the globe, even if not $a$ priori interested in African reparations, need to know that this claim holds an international law entitlement to the dismissal of capitalism. Another world is not only possible but also legally due ${ }^{75}$ as the current world system has been built on mass-scale organised crime for over 500 years.

\section{Conclusion}

To advance the realisation of global comprehensive reparations for transatlantic slavery and the Maafa/Maangamizi at large, urgently needed for securing human existence on earth, further research and communication on African and indigenous people's specific needs for reparations needs to occur among and by them globally. Transatlantic slavery and colonialism were fundamental

74 Wittmann (2013), p. 437.

75 Ibid., p. 442. 
in establishing the structures of the current world system, which has brought humanity to the brink of collapse.

Although this reparations process will be the most complex one ever dealt with and will also not magically whip up a miracle, it is integral and indispensable to global justice, peace and security. As ICJ Judge Patrick Robinson wrote in his commentary on my thesis, 'once it is established that slavery was illegal at the relevant time, the outstanding related questions, such as whether that practice rises to the level of genocide, will fall into place; by far the more thorny question is whether the practice of slavery was illegal at the relevant time. ${ }^{.76}$ Even in view of the immense complexity of this reparations claim, what can be ascertained already due both to expediency and international law requirements is that this reparations process cannot be limited to payments and will need to be led by African civil society. African continental and diaspora states will of course also have to be heavily engaged in such a process; however, the fact that they are also a product of transatlantic enslavement and colonialism is problematic and needs to be addressed in a comprehensive global African reparations approach. Further discussion on this point, however, is beyond the scope of this article.

Now, the question is how Western governments (and others, such as China, Saudi Arabia and other Arab countries) can be brought into this discussion. In all these countries, it will have to be the people, conceiving themselves as both local, national and global citizens, who realise the righteousness and necessity of the global African reparations claim and move power in their respective governments towards this cause. There is no alternative: human civilisation needs global African and indigenous peoples' reparations to heal the deep damage wrought by transatlantic slavery and colonialism which still have us in a tight grip. Therefore, Reparations Studies needs to be established as a scholarly discipline at the international level in universities. This article aspires to inspire and move this prospect closer to manifestation.

Nora Wittmann

University of Vienna

Email:noni81@gmx.net

\section{the global justicenetuork}

76 Correspondence with Patrick Robinson, President Judge of the UN International Criminal Tribunal for the former Yugoslavia, now at the ICJ (October 2012), on file with author. 